\title{
THE COLLIS PROCEDURE AND THE ACQUIRED SHORT ESOPHAGUS
}

\author{
Dragce Radovanovic $^{1,2}$, Mladen Pavlovic ${ }^{1,2}$, Dragan Canovic ${ }^{1,2}$, Dejan Lazic ${ }^{1,2}$ and Aleksandar Cvetkovic ${ }^{1,2}$, \\ Marko Spasic ${ }^{1,2}$, Bojan Stojanovic ${ }^{1,2}$ and Bojan Milosevic ${ }^{1,2}$ \\ ${ }^{1}$ Clinic for general and thoracic surgery, Clinical center Kragujevac, Kragujevac, Serbia \\ ${ }^{2}$ University of Kragujevac, Faculty of Medical Sciences, Kragujevac, Serbia
}

\author{
COLLIS PROCEDURA \\ I STEČENI KRATAK JEDNJAK \\ Dragče Radovanović ${ }^{1,2}$, Mladen Pavlović ${ }^{1,2}$, Dragan Čanović ${ }^{1,2}$, Dejan Lazić ${ }^{1,2}$, Aleksandar Cvetković ${ }^{1,2}$, \\ Marko Spasić ${ }^{1,2}$, Bojan Stojanović ${ }^{1,2}$ i Bojan Milošević ${ }^{1,2}$ \\ ${ }^{1}$ Klinika za opštu i grudnu hirurgiju, Klinički centar Kragujevac, Kragujevac, Srbija \\ ${ }^{2}$ Univerzitet u Kragujevcu, Fakultet medicinskih nauka, Katedra za hirurgiju, Kragujevac, Srbija
}

\section{ABSTRACT}

One of the most intriguing problems in modern esophageal surgery is the acquired short esophagus. While some authors recognize this entity, others deny its existence. There is a consensus about types of the short esophagus, its etiology and pathophysiology. Definitive diagnosis can be established only intraoperatively. There are a few surgical procedures for this problem, and most frequently is used Collis gastroplasty with fundoplication. In this review we emphasize recent literature data and further perspectives of the Collis procedure.

Keywords: Collis gastroplasty, acquired short esophagus, fundoplication

\section{INTRODUCTION}

Modern esophageal surgery involves more controversial questions which do not include the census of leading world authors. One of them is related to the problem of the acquired short esophagus. Nowadays according to many surgeons the acquired short esophagus is present, on the other hand the others deny it and say that they have never seen it even nor in large series of patients $(1,2)$. The radiologists first provided the definition of this medical entity to describe the intrathoracic gastroesophageal juction. However, surgical definition is based on impossibility of reduction GE juction in the abdomen intraoperatively. In later literature, the definition of the short esophagus accepted by most groups of the appointed in this area includes: 1) the short esophagus is diagnosed intraoperatively; 2) only after extensive mediastinal mobilization of the esophagus; 3 ) when the intraabdominal part of the esophagus is shorter $2-3 \mathrm{~cm}$ (measured down tension-free) (3). Horvath and his coworkers divided the short esophagus into three categories: 1) a true, nonreducible short esophagus; 2) a

\section{SAŽETAK}

Jedan od najinteresantnijih problema u modernoj hirurgiji jednjaka je stečeni kratakjednjak. Dokneki autori prepoznaju ovaj entitet, drugi negiraju njeno postojanje. Postoji konsenzus o vrstama kratkog jednjaka, njegovoj etiologiji i patofiziologiji. Definitivna dijagnoza se može postaviti samo intraoperativno. Postoji nekoliko hirurških procedura za rešavanje ovog problema, a najčešće se koristi Collis gastroplastika sa fundoplikacijom. U ovom radu dajeom pregled novijih podataka iz literature i dalje perspektive Collis procedure.

Ključne reči: Collis gastroplastika, stečeni kratak jednjak, fundoplikacija true, but reducible short esophagus; 3) an apparent short esophagus (4). Early reports in the literature show the different frequency in patients with esophageal disease, from $0 \%$ (by Hill and his coworkers) to $60 \%$ (by Pearson and his coworkers) (the data collected for the time period 19801991) $(2,3,5,6)$. Most data are based on the methods of precise gastroesophageal junction determination as well as the subjective gradation tension needed for the reposition of the suitable esophagus segment placed under the diaphragm. Later analysis shows that the actual incidence of the short esophagus is estimated to be $3-10 \%(4,6)$. The reasons for the increased percentage values (compared to values in surgical practice) are tertial specialized objects as well as the data collected from the retrospective studies. Nowadays the usage of proton pump inhibitor and performing minimally invasive procedure decrease serious esophageal disease leading to the its shortening. The aim of this paper is to emphasize recent literature data and further perspectives of the Collis procedure.
Corresponding author: Mladen Pavlovic Zmaj Jovina Street, No30 Clinic for General and Thoracic Surgery Clinical center Kragujevac Phone number +381641981075 Email address: mladenlucky@gmx.com 


\section{ETIOLOGY AND PATHOPHYSIOLOGY}

Intrinsic shortening of the esophagus results most commonly from the chronic inflammation that accompanies gastroesophageal reflux disease. The dysfunction of the lower esophageal sphincter allows either acid or alkaline (in case of duodenogastric reflux) contents to regurgitate into the esophagus. The squamous epithelium of the esophageal mucosa is not an effective barrier to refluxed juices, a 'burn' to the esophagus results, similar to that occurring in the case of ingested corrosive chemicals. It leads to a cascade of events: an inflammatory response, the inevitable stages of edema, infiltration with inflammatory cells, subsequent healing, and eventual fibrosis (7). The process eventually may involve the deeper muscular layers of the esophageal wall and may even extend transmurally into the periesophageal tissues of the mediastinum. Thus, the connection between esophagitis, stricture formation and the shortening of esophagus was established (8). The components of reflux content are acid, biliary and pancreatic juice, which allow the $\mathrm{H}+$ ion penetration into deeper wall layers of the esophagus, that consequently results in fibrosis. With repeated cycles of injury and repair overtime, functional and irreversible damage occurs to the involved esophagus. Contraction of the collagen in the trasmural fibrous scar can occur circumferentially, producing a peptic stricture or longitudinally, resulting in a short esophagus. Beside gastroesophageal reflux disease, there are other entities associated with the significant inflammatory reaction and the esophageal shortening: hiatus hernia type I and II, paraesophageal hernia hiatus type III, sarcoidosis, Barett's metaplasia, caustic ingestion, scleroderma and Crohn's disease.

\section{PREOPERATIVE AND INTRAOPERATIVE DIAGNOSIS}

As it is mentioned, the actual diagnosis of a short esophagus can be confirmed just in the operating room. However, very precise preoperative findings are necessary for each patient being prepared for an operation. In that way, preoperative findings can confirm surgeon's suspicion for a short esophagus. These indicators are: anamnestic data related to a long year gastroesophageal reflux disease (40\% patients have complications - macroscopic esophagitis, Barett's esophagus, peptic stricture of the esophagus or an acquired short esophagus) and early unsuccessful antireflux procedure $(6,9-11)$. Preoperative findings show the frequency of the acquired short esophagus at the following entities: manometric - absence of distal high pressure zone, hypo or aperistalsis of distal esophagus; esophagogastroduodenoscopy - identification of the GE junction (5 $\mathrm{cm}$ or more) above diaphragm hiatus; moderate or severe esophagitis, the presence of early peptic stricture, and Barett's esophagus; barium esophagram - a large esophageal hiatus hernia type I which can not reduce spontaneously in vertically position; a large hiatus hernia type III, and stricture $(5,8,11,12)$. Intraoperative findings may cause a problem for a surgeon because of abnormal anatomic relations, complicated identification of gastroesophageal junction, presence of pneumoperitoneum raising the diaphragm and give a false diagnosis $(1,5,10,12,13)$.

\section{THE COLLIS PROCEDURE}

If intraoperatively 2.5 to $3 \mathrm{~cm}$ length of the esophagus is confirmed, several surgical options for treatment are reported. One of well known is the lengthening procedure. Collis first described the operation that bears his name in 1957 because he had been unsatisfied with problems being caused with the short esophagus. This lengthening procedure was performed through a thoracoabdominal incision. Collis emphasized the fact that mediastinal mobilization of the esophagus to the level of the aortic arch was sufficient to perform the suitable antireflux procedure. When additional length was needed, he created a gastric tube (the Collis gastroplasty) by dividing the stomach between two clamps placed opposite of the small curvature with a bougie. Unfortunately, the Collis procedure alone as well as the lengthening procedure was not sufficient to control reflux for a long time. So, Pearson and his coworkers first completed transthoracic Collis gastroplasty with Belsey fundoplication (6). They pointed out an additional advantage of this combined procedure: the fundoplication sutures are placed into the healthy issue of the esophagus. Orringer, Henderson and Sloan advocated the Collis - Belsey procedure and reported the excellent results - as high as $85 \%$ symptomatic reflux control at 10 years of follow-up (14). Both ways considered a transthoracic approach because it was difficult to perform an adequate esophageal mediastinal mobilization. In 1986. the usage of newly developed gastrointestinal stapling devices helped Steichen and his coworkers to describe an effective open transabdominal procedure for performing Collis gastroplasty using EEA and GIA stapling devices (14-16). The first one was used to create a buttonhole in the gastric fundus after previous mobilization. The second one used to create neoesophagus was placed through the gastric buttonhole (17). Langer, Demos, Bingham first used 'uncut' Collis. Later, Evangelist, Paris, Van Kemmel, Piechler and Payne used it as well $(18,19)$. This method considers the gastroplasty tube created by mucosal apposition of the anterior and posterior stomach wall from the proximal smaller curvature by the use of a $3 \mathrm{~cm}$ linear stapler, applied along an inlaying no. 48 or 50 French bougie held against the small curvature. The acquired tube like this is not separated from the gastric fundus by transection. Then, previous mobilized fundus is used for total fundoplication and the fundic wrap is sutured immediately anterior to the staple line. If the fundus is not appropriate because of earlier surgeries, the modified Collis-Nissen procedure by Jeyasingham is used. After formation of the gastroplasty tube, the fundus is opened 
longitudinally and then closed transversely, as for a pyloroplasty. This closure provides a widened fundus which create the fundoplication wall. In that way, more fundi used as plication wall are given. The approach to these methods is transtoracal. Introducing laparoscopic surgery as well as maintaining the benefits of a less invasive approach reduces the usage of open approaches for creating neoesophagus and antireflux procedures. In the middle of the 1990s Swanstrom placed endoscopic linear stapler across the right mediastinal pleura and created neoesophagus in order to perform the fundoplication using laparoscopic techniques. In 1998. Johnson, Oddsdottir and Hunter performed laparoscopic procedure which initially had been described by Steichen (20). Awad placed the articular stapler through the left hemithorax and created the gastroplasty. One of the last modified Collis procedures started to be used in surgery in 2004. by Terry, Vernon and Hunter, Lin and coworkers and Hoang (21). The authors performing laparoscopic gastroplasty and fundoplication noticed a significant number of apex fundus ischemia. It made them to modify the procedure and describe so-called stapledwedge gastroplasty. The potential ischemic topic of fundus is removed with creating first transversal and then vertical stapled line. The transection of fundus is done transversely with the stapler and it creates another stapler which is used for performing the gastroplasty in a regular way (22).

\section{DISCUSSION}

The Collis procedure has been used clinically for 60 years as a standard lengthening technique in the treatment for the short esophagus. Initially, the procedure was performed with open approach through thorax or abdomen. Then its performing with development of gastrointestinal EEA, GIA, endoscopic and articular staplers became standard, safe and routine. Beside constant progress and modification, some complications are noticed by the long term following the patients. These ones may be early and late. All patients being prepared for the Collis gastroplasty followed the fundoplication experience complications relating to all antiflux procedure. Early complications include: dehiscence (leaks) of the gastroplasty tube, necrosis, postoperative dysphagia and early reflux. All these complications occur refer to technical omission during the performing operation. Postoperative dehiscence occurs in about $1 \%$ of all case, on the tubus alone, new created fundus or at the angle between them. Nowadays, for this reason, most authors oversew the staple line with a continuous one layer absorbable suture. Necrosis of gastroplasty is a very rare event and theoretically may occur when the gastroplasty is utilized following subtotal gastrectomy with division of the main left gastric artery. The incidence of postoperative leaks following gastroplasty is about $1 \%$. Postoperative dysphagia may occur from the complications related to the antireflux procedure but may also result from a poorly created neoesophagus. Most authors preventively advocate utilizing a 50-60 French bougie in creating the gastroplasty, however Collis utilized as narrow a tube as a no. 32 French bougie. Technical failure of the antireflux procedure is the usual cause of early reflux. Late complications following the gastroplasty include: recurrent reflux, diverticulum of the gastroplasty tube and the carcinoma development. Henderson and Orringer described significant reflux (15$20 \%$ cases) occurring after partial fundoplication following each Collis procedure, so they proposed total fundoplication after this esophagus elongation procedure (16). Too long fundoplication results in prolonged dysphagia and now most authors recommend a total fudoplication of no more than $1.5 \mathrm{~cm}$ with the proximal suture placed in healthy part of esophagus. The incidence of persisting mild or moderate dysphagia occurs in $10-15 \%$ of gastroplasty operations. Diverticulum formation occurs in the proximal portion of the gastroplasty, if the fundoplication is too tight in the distal part which results from a technically bad performed antireflux procedure $(23,24)$. Carcinoma in neoesophagus may occur unless early carcinoma of esophagus is diagnosed initially in the distal part or in the area of dysplasion of esophageal mucosa after gastroplasty formation $(6,10,25)$. A special problem is existence of squamous mucosal islands producing hydrochloric acid. Mor and his coworkers said that reduction the amount of acid from new created tubus in the patients with NissenCollis gastroplasty took more time compared to the controllable group (patients without reflux) $(24,26)$. For these reasons, the patients with reflux or abnormal production of acid in tubus need the usage of proton pump inhibitor for a long time $(23,27,28)$. Generally speaking, this method solves the problem of short esophagus. It provides amotility segment producing acid in some cases, so it is called nonphysiologic treatment $(10,12,14,16)$. The Collis procedure is used successfully in the cases of reoperation after failed antiflux procedure (Deschamps in $62.7 \%$ cases and Luketich in $52.5 \%)(18,25,29,30)$. Pearson and Orringer first described that mortality ranged from $0.5-1,1 \%$. Long term results show a different percentage of successful neoesophagus formation, from 59-80 \% $(5,6,10,31,32)$.

\section{CONCLUSION}

In spite of possible complications occurring during the formation of neoesophagus, Collis designed a gastroplastic tubus in order to lengthen esophagus in the cases of the acquired short esophagus. The gastroplastic tubus combined with antireflux procedure was an excellent approach to solving the problem in distal esophagus with the decreased rate of mortality. It is utilized in the patients having a lot of risk of reccurence after standard antireflux procedures. It includes: the acquired short esophagus and peptic stricture, obesity, recurrent reflux after various antireflux procedure and combination of hiatus hernia type I and II and paraesophageal hiatal hernia type III. This procedure is contraindicated after myotomy of lower esopha- 
geal sphincter and not utilized in the patients with serious motility disorder. The Collis-Nissen procedure has an established excellent long-term success rate for this complex problem. Methods to treat the short esophagus, aside from the Collis gastroplasty, have poorer long -term results, with increased rates of complications. With the development of endoscopic Collis techniques, coversion to an open laparotomy/thoracotomy when a short esophagus is encountered is no longer necessary. The choice of the laparoscopic/thoracoscopic single-stapler technique or the laparoscopic double - stapler technique should be left to the surgeon. Both procedures can be performed safely and offer all the benefits of laparoscopic surgery. Even though a lengthening procedure is the best choice, the Collis gastroplasty is a nonphysiologic treatment for a complex problem and requires long-term follow-up.

\section{REFERENCES}

1. Madan AK, Frantzides CT, Patsavas KL. The myth of the short esophagus. Surg Endosc. 2004 Jan;18(1):31-4.

2. Herbella FAM, Patti MG, Del Grande JC. When did the esophagus start shrinking? The history of the short esophagus. Dis Esophagus. 2009;22(7):550-8.

3. Mattioli S, Lugaresi ML. Lengthening Gastroplasty for Managing Gastroesophageal Reflux Disease and Stricture. In: Ferguson MK, editor. Difficult Decisions in Thoracic Surgery: An Evidence-Based Approach. London: Springer London; 2007. p. 305-17.

4. Horvath KD, Swanstrom LL, Jobe BA. The short esophagus: pathophysiology, incidence, presentation, and treatment in the era of laparoscopic antireflux surgery. Ann Surg. 2000 Nov;232(5):630-40.

5. Durand L, De Anton R, Caracoche M, Covian E, Gimenez M, Ferraina P, et al. Short esophagus: selection of patients for surgery and long-term results. Surg Endosc. 2012 Mar;26(3):704-13.

6. Kunio NR, Dolan JP, Hunter JG. Short Esophagus. Surg Clin. 2016 Sep 18;95(3):641-52.

7. Gastal OL, Hagen JA, Peters JH, Campos GM, Hashemi M, Theisen J, et al. Short esophagus: analysis of predictors and clinical implications. Arch Surg. 1999 Jun;134(6):633-8.

8. Gelberg HB. Comparative Anatomy, Physiology, and Mechanisms of Disease Production of the Esophagus, Stomach, and Small Intestine. Toxicol Pathol. 2014 Jan 1;42(1):54-66.

9. Herbella FAM, Del Grande JC, Colleoni R. Short esophagus: literature incidence. Dis Esophagus. 2002;15(2):125-31.

10. Worrell SG, Boys JA, DeMeester SR. Identification and Management of a "Short Esophagus" and a Complex Hiatus. In: Aye WR, Hunter GJ, editors. Fundoplication Surgery: A Clinical Guide to Optimizing Results. Cham: Springer International Publishing; 2016. p. 31-7.
11. Jobe BA, Richter JE, Hoppo T, Peters JH, Bell R, Dengler WC, et al. Preoperative Diagnostic Workup before Antireflux Surgery: An Evidence and Experience-Based Consensus of the Esophageal Diagnostic Advisory Panel. J Am Coll Surg. 2016 Sep 18;217(4):586-97.

12. Teitelbaum EN, Soper NJ. The Short Esophagus. In: Swanstrom LL, Dunst MC, editors. Antireflux Surgery. New York, NY: Springer New York; 2015. p. 177-87.

13. Bochkarev V, Lee YK, Vitamvas M, Oleynikov D. Short esophagus: how much length can we get? Surg Endosc. 2008 Oct;22(10):2123-7.

14. Scott-Conner CEH, Chassin JL. Transthoracic Gastroplasty (Collis) and Nissen Fundoplication: Surgical Legacy Technique. In: Scott-Conner EHC, editor. Chassin's Operative Strategy in General Surgery: An Expositive Atlas. New York, NY: Springer New York; 2014. p. 223-32.

15. Bathla L, Legner A, Tsuboi K, Mittal S. Efficacy and feasibility of laparoscopic redo fundoplication. World J Surg. 2011 Nov;35(11):2445-53.

16. Jones R, Tadaki C, Oleynikov D. Laparoscopic redo paraesophageal hernia repair with collis gastroplasty for shortened esophagus. Surg Endosc. 2015;29(3):736.

17. Fréchette É, Duranceau A. Management of the Short Esophagus. In: Ferguson MK, Fennerty MB, editors. Managing Failed Anti-Reflux Therapy. London: Springer London; 2006. p. 151-62.

18. Pera M, Deschamps C, Taillefer R, Duranceau A. Uncut Collis-Nissen gastroplasty: early functional results. Ann Thorac Surg. 1995 Oct;60(4):915-20; discussion 921.

19. Demos NJ. Stapled, uncut gastroplasty for hiatal hernia: 12-year follow-up. Ann Thorac Surg. 1984 Oct;38(4):393-9.

20. Johnson AB, Oddsdottir M, Hunter JG. Laparoscopic Collis gastroplasty and Nissen fundoplication. A new technique for the management of esophageal foreshortening. Surg Endosc. 1998 Aug;12(8):1055-60.

21. Terry ML, Vernon A, Hunter JG. Stapled-wedge Collis gastroplasty for the shortened esophagus. Am J Surg. 2004 Aug;188(2):195-9.

22. Jolley J, Kindel T, Oleynikov D. Paraesophageal Hernia Repair and Collis Gastroplasty. In: Fisichella MP, Patti GM, editors. Atlas of Esophageal Surgery. Cham: Springer International Publishing; 2015. p. 63-73.

23. Nason KS, Luketich JD, Awais O, Abbas G, Pennathur A, Landreneau RJ, et al. Quality of life after collis gastroplasty for short esophagus in patients with paraesophageal hernia. Ann Thorac Surg. 2011 Nov;92(5):1851-4.

24. Mor A, Lutfi R, Torquati A. Esophageal acid-clearance physiology is altered after Nissen-Collis gastroplasty. Surg Endosc. 2013 Apr;27(4):1334-8.

25. Pfister AW, Djourno XB, Avaro JP, Ouattara M, Trousse D, Doddoli C, et al. Surgical results of type III and IV hiatal hernia with left thoracotomy. Acta Gastroenterol Latinoam. 2011 Mar;41(1):29-35. 
26. Jobe BA, Horvath KD, Swanstrom LL. Postoperative function following laparoscopic collis gastroplasty for shortened esophagus. Arch Surg. 1998 Aug;133(8):867-74.

27. Garg N, Yano F, Filipi CJ, Mittal SK. Long-term symptomatic outcomes after Collis gastroplasty with fundoplication. Dis Esophagus. 2009;22(6):532-8.

28. Yau P, Watson DI, Jamieson GG, Myers J, Ascott N. The influence of esophageal length on outcomes after laparoscopic fundoplication. J Am Coll Surg. 2000 Oct;191(4):360-5.

29. Awais O, Luketich JD. Management of giant paraesophageal hernia. Minerva Chir. 2009 Apr;64(2):159-68.
30. Mittal SK, Shah P. Current readings: Failed hiatal hernia repair. Semin Thorac Cardiovasc Surg. 2014;26(4):331-4.

31. Shapiro M, Chin EH. Transthoracic Collis Gastroplasty and Nissen Fundoplication. In: Hoballah JJ, Scott-Conner MD HCE, editors. Operative Dictations in General and Vascular Surgery. New York, NY: Springer New York; 2012. p. 45-9.

32. Tsuboi K, Omura N, Yano F, Hoshino M, Yamamoto SR, Akimoto S, et al. A novel laparoscopic approach for severe esophageal stenosis due to reflux esophagitis: how to do it. Surg Today. 2015 Feb;45(2):253-7. 